\title{
Agency for the Development of Educational Management in-Service Training Program of Secondary School Heads in Enhancing Communication Skills for Human Relations in Tarime District, Tanzania
}

\author{
Annamary Peter \\ Masters' Student, Mwenge Catholic University, P.O Box 1226, Moshi-Tanzania \\ Prof. Evans Ogoti Okendo (Ph.D.) \\ Director of Postgraduate Studies, Mwenge Catholic University, P.O Box 1226, Moshi-Tanzania \\ Rev. Dr. Eugene Lyamtane \\ Lecturer, Mwenge Catholic University, P.O Box 1226, Moshi-Tanzania
}

\begin{abstract}
The research is financed by Annamary Peter (Masters' Student at Mwenge Catholic University, Moshi-Tanzania) Abstract

This study aimed to investigate how Agency for the Development of Educational Management (ADEM) inservice training program enhances communication skills for human relations skills of Public Secondary school heads in Tarime District, Tanzania. The study was guided by one research question. Convergent design under mixed approach was used. The study targeted used a sample of 8 schools, with 8 heads of schools, 80 teachers, 16 non teaching staff and 192 form three students. Data was collected using questionnaires for school heads, teachers and students together with interview guide for non teaching staff. Validity of instruments was ensured by requesting two research experts from Mwenge Catholic University and Validity of qualitative data were through member checking, peer review and triangulations. The reliability of the items was tested by using Cronbachs Alpha formula using Likert scale questions and found to be 0.783 and 0.720 for teachers and students respectively. The descriptive statistics were analysis using mean scores, frequencies and percentages. Analysis of qualitative data was through thematic and transcribed data were presented in narrations form supported by direct quotations. The study found that ADEM in-service training program enhances communication skills of school heads for human relation by providing them the skills to involve staff members and students in problem solving, conducting meetings and listening and understanding abilities. The study recommend that public school heads especially those who never attended ADEM in-service training program should be equipped with communication skills for they lack some skills for human relation.
\end{abstract}

Keywords: Communication skills, Human relations, Agency for the Development of Educational Management DOI: $10.7176 / \mathrm{JEP} / 12-27-10$

Publication date:September $30^{\text {th }} 2021$

\section{Introduction}

The contribution of the secondary school head on the realization of national goals is of great importance. This is true because the school head is charged with mobilization and management of all the people involved at the school level since they lead teachers, students and other staff members towards the achievement of objectives of the school and that of the Nation at large. Handling people and equipments is not an easy task; It requires managerial skills to influence this relationship so as to achieve the expected goal. Each individual in a school has unique characteristics and tactics hence skills are required to make them fulfil the organization's objectives (Kambe, 2011). This is true because the school organisation plays an essential part to the lives of people as it prepares future responsible citizens through the teaching staff and non teaching staff under the supervision of a school head as the leader.

Since the overall effectiveness of the school depends greatly on the influence of the school head, he/she should receive special training (Dillon-Peterson, 1986) in Mirunde (2015). When public secondary school heads are appointed they are expected to be taken through the required skills needed to effectively manage the school; this call for the need of in-service training program to equip them with the required skills for them to efficiently and effectively manage the school. Githiari, (2017) emphasis that school heads are expected to be highly skilled leaders in order to be effective in attaining school goals.

In Tanzania the in-service training program for Educational management is conducted by the Agency for the Development of Educational Management (ADEM) which is an Executive Agency established under the Executive Agencies Act Cap.245 of 1997 with the mandate of improving education management through provision of education management training, research and consultancy services (Mgullah, n.d). Moreover, the establishment of the Agency is a push to the Government initiatives for realization of Vision 2025 and the 
Tanzania Education and Training Policy (TETP) of 2014 which require graduates of each level of education to have skills to sustain peace, to endure and resolve conflicts in a society (TETP, 2014). To ensure the implementation of this part of the policy, the education sector needs knowledgeable personnel who are able to supervise and manage the provision of education to the public by creating a conducive peaceful environment for learning and future responsible citizen. The policy directs education for peace should focus on helping students to have the capacity to stop and resolve conflicts peacefully when such conflicts occur among the people, between the people or among groups involved in schools.

The Agency has the core function of training educational personnel in educational leadership, management and administration for the purpose of raising the standard of education in Tanzania. The institutional objective is therefore, to provide educational officials with skills in addressing challenges in the education sector and schools in particular so as to facilitate graduates to efficiently manage their institutions as well as advance themselves academically. ADEM is the only government agency in Tanzania where school managers and education personnel are equipped with managerial skills and knowledge for the purpose of enhancing school and general educational leadership, management and administration (Mgullah, n.d).

In nut shell, the implementation of in-service program is expected to improve school leadership of Heads of secondary schools (HoS) on the managerial skills particularly human resource management, financial management and conflict management hence academic performance and quality education delivery. This is done by equipping them with the managerial skills required to effectively lead their schools. The managerial skill on human resource management is found to be more useful compared to other two managerial skills because when it is well acquired it is used to solve conflicts and also to manage the school finances. The handling of human resources requires the school head to have managerial skills such as interpersonal relation skills, supervision skills, communication skills, conflict management skills, financial management skills and decision making skills. The quality of discipline among students reflects the quality of leadership of HoS. The way school heads create conducive working environment to their staff call for proper use of managerial skills.

The provision of an in-service training to HoS is expected to ensure smooth running of our school. However, with time educational challenges have been observed in Secondary Schools in Tanzania which indicate the underperformance of school heads due to different challenges facing schools despite attending the in-service training program. Most of HoS have attended in-service training to acquire the managerial skills; which are expected to be used to manage both teaching and non teaching staff. The introduction of such training was meant to cart the anticipated problems commonly experienced by HoS. For example in Kenya lack of training in managerial skills has been largely responsible for a great deal inefficiency and ineffectiveness observed in performance of many educational systems in Africa (Githiari, 2017).

In Tanzania, Kaluma (2017) found that there are conflict between individual members, intergroup and conflict between two or more individuals in schools in Shinyanga, Tanzania due to lack of skills in conflict resolution by secondary school heads and lack of proper communication. The Regional Commissioner of Shinyanga Zainab Telack on Feb $4^{\text {th }} 2020$ during her meeting with all school heads ordered them to supervise teaching and learning activities, ensure effective communication; keep their doors open and being friendly to teachers, students and parents to create creative climate. In addition she urged school heads to avoid unnecessary conflicts and instead to ensure good working relationships (The Citizens, 2020, February, 4). In Tarime District the department of secondary education had put forward one of their responsibilities to be encouraging discipline control of teachers, non teaching staff and students of all secondary schools in the District so as to avoid conflict and ensure conducive environment.

The fulfillment of this responsibility requires $\mathrm{HoS}$ to have the special leadership skills. In Educational Institutions, management skills equip leaders with the creative touch in human relations and management which help them to evaluate the performance of a school both at the academic and co-curricular levels. Handling human resources the school head should possess managerial skills which are acquired learning abilities to solve different challenges. The skilled school head need to have communication skill that is the ability to convey the message effectively to subordinates. It is essential for a school head to communicate knowledge, instructions, purpose, goal, mission and vision of the school (Kambe, 2011)

The current study investigated on the contribution of ADEM in-service training program of secondary school heads in enhancing communication skills for human relations in Tarime District where human relation skills have been a challenge. Masalu (2018) investigated on students' indiscipline cases in secondary schools in Tanzania and found out that the common acts of students' indiscipline are caused mostly by lack of friendly school environment. He showed the impacts of indiscipline cases to be poor academic performance, loss of teaching morale, distraction of classes, and misunderstanding between teachers and parents as well as between teachers and students. The Citizen reported that on Thursday June $7^{\text {th }} 2018$ between July 2017 and May 2018,27 primary and secondary school teachers had been expelled from their jobs in Tarime District over work-related conduct, including absenteeism and indiscipline as it was narrated by the assistant secretary of the Teachers Service Commission (TSC) in Tarime District. 
The report furthermore indicated that four teachers were taken to court because the offences they were accused of involved crime while 19 teachers were warned and required not to repeat similar mistakes (Ogutu, 2018). In addition, the Acacia North Mara's Acting Manager of Sustainable Community, Sadalla Hamisi, had organized the seminar in 2018 so as to impart capacity building to teachers to effectively carry out their duties and to reduce indiscipline cases of teachers. Mabela (2016) conducted a study on the role played by school management in handling career-related stress in secondary schools in Tarime District. The study showed that male secondary teachers, diploma holder teachers, teachers with 4-7 years of work experience had high Career Related Stress compared to other groups. This raises the question as to whether these secondary school heads are well equipped with communication skills to enforce human relations at their schools or not. This called for an investigation on whether the in-service training program equips them with the necessary managerial skills for them to handle different challenges on human relations pertaining to all the people involved in their schools or not.

Onguko et al. (2008) observed that there is a shortage of training institutes for educational leaders in this country something which implies that many schools heads are promoted to headship positions without necessary skills. It was also observed by Kayiwa (2011) in Uganda that the insufficient training of head teachers reduced school performance. Since ADEM is the only agency where after being appointed, secondary school heads are usually trained, and the training programs offered by this agency usually last for short periods of time, ADEM itself seems to lack a comprehensible plan on how to run these programs (Materu, 2016). Besides, there is an increase in the number of both public and private schools and yet there has been far less concern with the preparation and development of school leaders in Tanzania. Under this need there is a necessity for assessment of in-service training program for secondary school heads to ensure that the current and future leaders develop skills especially in communication to acquire the capacity to lead and transform the school education system into the best in the world (Auma, 2014). Therefore, this study investigated how ADEM in-service training program enhances communication skills on management of human relations to public HoS in Tarime District.

\section{Statement of the Problem}

Underperformance of secondary school heads which has been a problem in Tanzania could be traced back to lack of leadership skills on handling people and different challenges. Secondary school heads in Africa particularly Tanzania face different challenges in managing human relations but lack training in leadership and management to solve them. This is because classroom teachers for example, are promoted to headship without essential leadership skills (Kuluchumila, 2014). This problem need to be addressed by bridging the gap of performance through in-service training to secondary school heads to equip them with the communication skills needed to handle different challenges in their schools.

The Government of Tanzania established the in-service training program for Educational management which is conducted by the Agency for the Development of Educational Management (ADEM) which has the mandate of improving education management through provision of education management training, (Mgullah, n.d). In a nutshell the Agency through INSET is expected to equip school heads with skills on the management of human relations for them to face different challenges occurring at their schools. Despite the training provided, there are still educational challenges in Secondary Schools which indicate the underperformance and incompetence in their leadership.

Various studies conducted in education sector in various countries in Africa, Asia and Europe revealed that in-service training can create a world of difference in the efficiency in managing human relations in School (Kambe, 2011). Scholars who have addressed the problem such as Mabela (2016), Janse (2019), Masalu (2018), Masao (2017) and Kaluma (2017), in their findings they found out that some of HoS in Tarime District demonstrated incompetence in their leadership. Despite the efforts in place to provide the program, together with few studies conducted in this area, its quality as demonstrated by HoS in their work place is still questionable. Therefore this study focused on how ADEM in-service training program enhances communication skills on Human relations skills of public HoS in Tarime District.

\section{Research Question}

How does ADEM in-service training program of secondary school heads enhance communication skills for human relations in Tarime District?

\section{Significance of the Study}

The findings of this study is useful to staff members and students because their school heads will be able to use communication skill effectively to provide all the information needed to accomplish the task and specify clearly the results needed in schools. In addition school heads through communication will have the ability to make a follow up and accountability and gives the required information on time. Moreover, through communication skill will be available with open door to staff members and students and to communicate knowledge, vision and 
mission to staff members and students. Furthermore, all school members will be involved in problem solving especially in meetings being respected valuing their inputs.

Furthermore this study is used as a reference study to the future researchers to investigate the same problem in other areas apart from Tarime District to find out how useful is communication skills by the HoS in managing human relations in their school. This study is useful to the Agency for the Development of Educational Management (ADEM) to consider how they can improve the in-service training program to secondary school heads especially those who never attended the program for them to acquire communication skills to enhance human relations. This study also confirms and validates human relation and human capital theories because communication is one of the variables explained among others which are: motivation, influence, cooperation in problem solving, leader-member relations, lower indiscipline cases.

\section{Theoretical Framework}

This study was grounded on Human Relations Theory of management which was developed by Marry Parker Follet in 1918 and later supported by Elton Mayo in 1950. The theory explains the relationship between the leader and followers as the sensitive to motivation and satisfaction. It recognises the subordinates as human beings with their needs, beliefs, perceptions and values that they should be given opportunities to enhance personal growth and development that the leader should make them cooperate to achieve the organisational aims. Its main features are: communication, motivation, influence, cooperation in problem solving and coordination as the result of reciprocal understanding of all factors in the situation (Luenendonk, 2019).

The theory explains further that all leaders work through people and with people, hence they must be sensitive to the human factor and organization structures should allow for free interplay since leadership is about shared responsibilities and therefore it is geared to the Decentralisation of the system. Communication is taken to be very important and a reciprocal for the mutual understanding between the leader and the subordinates; this is to be used to solve different challenges which may arise between the two parties because of their differences (Janse, 2019).

Moreover the strength of the theory is that it gives rooms to the heads of school to consider the subordinates in their human factors. According to theory the school heads is required to have the necessary skills towards successful leadership which are: interpersonal skills, communication skills and decision making skills. Since the leader works with the people and the people then this is true to the HoS who coordinates all the activities of the staff members and students towards the expected outcome of the school. They are to consider their needs, values, perceptions as they involve them in different decisions and then leads them towards the required goals of the school and the goals of the Nation. With this theory the head of school uses the leadership skills together with subordinates to solve different challenges at school (Young, 2017).

However the weakness of the theory is the heads of school may concentrate only on the human factor and forget the other responsibilities of each subordinate. Also the theory was developed long time ago and as the time goes there are other changes according to time. Teachers and students of the current time are not ready to accept everything told by the leader as opposed to those times. In today's time the HoS should be well equipped by the human relation skills to enable them face different challenges. The theory also does not show how the leader acquires these skills for the successful leadership. It takes the consideration of the skillful leader who knows everything on leadership.

The researcher applied this theory to show how HoS can influence their subordinates towards the success that this is done through people and with people. By using the communication skill which is one of the component of human relation. HoS considers subordinates as human beings who have perceptions, values and need to be motivated towards the expected outcomes. With this theory the researcher emphasized on how the school head should consider subordinates working with them in solving different challenges at school.

\section{Literature Review}

This section focuses on reviewed empirical studies related to the contribution of ADEM in-service training program of public secondary school heads in enhancing communication skills in managing human relations in their schools.

Dawn (2016) conducted a study on Communication behaviors of principals at high performing elementary schools in Virginia. The qualitative data was derived from semi-structured interviews with 8 of these principals, surveys of principals and publicly available data about these schools. Analysis of the self-reported information resulted in 11 specific communication strategies practiced by most or all of the principals in the participating high performing elementary schools. Further uncovered were 5 themes of communication in leadership which include a student-centered approach to decision-making, transparency of decision-making, shared decisionmaking with principal and teachers, the role of faculty trust, and principal preparation. Specific principal communication behaviors with teachers were implemented in motivating teachers toward earning highperforming status. These included frequent face-to-face and personal communications, minimal use of whole- 
school meetings, and weekly principal participation in grade level meetings. The researcher discovered the themes for communication skills at primary school level which may be different at secondary level if in-service training program to school heads can bring this difference for effective management of human relations. This study investigated how ADEM enhances communication skills to HoS for them to manage human relations.

Mohamed, (2012) conducted a study on effective communication of Urban and rural school leaders in Egypt. The target sample was school heads, teachers, students, and parents from selected urban and rural schools in Egypt. The data was collected through semi structured interviews focussing on the various aspects of communication used by school leaders to create a vision of learning, to develop the school culture, to promote instructional programs for student's learning, and to encourage professional development of teachers. Responses from all participants address each of the aspects of communication used in the identified schools and provided the findings which suggested that communication was not effective in connecting all the groups. The researcher showed how communication is important to connect the school heads and other groups such as teachers, students and parents but how the skill can be enhanced. The current research investigated how in-service training to heads of schools enhances communication skills for them to solve the challenges on human relations.

Mathew (2017) conducted a study on the influence of the heads of schools' human relation skills on job performance of teachers in public secondary schools in Moshi Municipality Tanzania. The study employed quantitative research approach where by the cross sectional survey design was used. A sample of 80 participants was selected by using probability sampling technique which are stratified and simple random sampling technique. The study found that effective and defined communication skills of the heads of schools influence positively teachers' motivation in terms of job skills, meeting of goals, decision making, conflict resolution and problem solving skills for schools. Though the researcher found that effective and defined communication skills of the heads of schools influence positively teachers' motivation, the study did not indicate if these skills are enhanced through in-service training or not. The study investigated how heads of secondary schools are equipped by communication skills for human relations through in-service training.

Kanani (2018) conducted a study on effectiveness of administrative communication system on teachers' performance in secondary schools in Singida Municipality, Tanzania. The study involved both qualitative and quantitative research approaches which include cross-sectional and phenomenology research design. The population was the Municipality secondary school officer, all head of secondary schools and all teachers. The sample size comprises of 111 participants where 100 were teachers, 10 were head of schools and 1 MSEO. The stratified and simple random and purposive sampling techniques were employed. The findings show that the implementation of effective administrative communication portrays significant impact to teachers' performance and their commitment. The study showed how important administrative communication is to teachers' performance but it did not show if the skill is enhanced by the in-service training program. This research found out how ADEM in-service training enhances communication skills to HoS on human relations skills.

The reviewed studies on how ADEM in-service training program of secondary school heads is enhancing communication skills on management of human relations in secondary schools suggest that communication was not effective in connecting teachers, students and supporting staffs with the school head. On the other hand the studies show that effective and defined communication skills of the heads of schools influence positively teachers' motivation in terms of job skills, meeting of goals, decision making, conflict resolution and problem solving skills for schools. Also specific communication behaviours of the school head to be implemented in motivating teachers were revealed. These studies did not show how the defined communication and specific communication emerged from studies can be enhanced to school heads and if at all in-service training can influence skills to effect human relation. Moreover among the reviewed studies none of the studies were conducted in Tarime District. The current study investigated how HoS are equipped with communication skills for handling human relations through ADEM in-service training program.

\section{Methodology}

This study employed mixed method in which convergent design was used. The design was used because of the possibility of collecting both qualitative and quantitative data to respond to the research question thus properly addressing the research problem. The target population of the study was all the 32 public secondary schools in Tarime District; 32 heads of secondary school, 500 teachers, 100 non-teaching staff and 1600 form three students of secondary schools in Tarime District. The study employed stratified and simple random sampling techniques to sample 8 schools, 80 teachers, 16 non teaching staff and 192 form three students. Eight (8) Public secondary school heads were not sampled but were included directly according the position they held thus the total sample was 280. Data collection instruments were questionnaires for teachers, school heads and students together with interview guide for non teaching staff.

Validity of instruments was ensured by requesting two research experts from Mwenge Catholic University to ensure content validity. Validity of qualitative data was done through triangulation of information. Pilot testing of instruments was done in two schools found in Tarime District which were not involved in actual data 
collection. The reliability of the items was tested by using Cronbachs Alpha formula using Likert scale questions and found to be 0.783 and 0.720 for teachers and students respectively. The descriptive statistics were analyzed frequencies, means and percentages with the aid of computer software and presented using tables. Analysis of qualitative data was done through thematic and transcribed data were presented in forms of narrations and supported by direct quotations.

\section{Findings and Discussion}

The study sought to find out the contribution of ADEM in-service training program of public secondary school heads in enhancing communication skills in managing human relations. The responses were collected from the heads of schools, teachers, non teaching staff and students. The researcher investigated several aspects of communication in the schools that could be the mechanisms for managing human relations. Responses are presented in table 1, 2, 3 and 4.

Table 1 Summary of Teachers' responses on communication skills of Heads of Schools $\mathrm{N}=76$

\begin{tabular}{|c|c|c|c|c|c|c|c|c|c|c|}
\hline & \multicolumn{2}{|c|}{$\begin{array}{c}\text { strong } \\
\text { disagree }\end{array}$} & \multicolumn{2}{|c|}{ disagree } & \multicolumn{2}{|c|}{ undecided } & \multicolumn{2}{|c|}{ agree } & \multicolumn{2}{|c|}{$\begin{array}{l}\text { strong } \\
\text { agree }\end{array}$} \\
\hline & $\mathrm{f}$ & $\%$ & $\mathrm{f}$ & $\%$ & $\mathrm{f}$ & $\%$ & $\mathrm{f}$ & $\%$ & $\mathrm{f}$ & $\%$ \\
\hline $\begin{array}{l}\text { The head tries to provide all information needed } \\
\text { to accomplish the task }\end{array}$ & 7 & 9 & 10 & 13 & 3 & 4 & 38 & 50 & 18 & 24 \\
\hline $\begin{array}{l}\text { The school head specifies clearly the results } \\
\text { needed }\end{array}$ & 8 & 11 & 17 & 22 & 0 & 0 & 37 & 49 & 14 & 18 \\
\hline $\begin{array}{l}\text { The school head involves teachers in problem } \\
\text { solving }\end{array}$ & 7 & 9 & 12 & 16 & 1 & 1 & 40 & 43 & 16 & 21 \\
\hline $\begin{array}{l}\text { The head makes follow up and maintain } \\
\text { accountability }\end{array}$ & 6 & 8 & 14 & 18 & 0 & 0 & 41 & 54 & 15 & 20 \\
\hline The head gives the required information on time & 10 & 13 & 13 & 17 & 4 & 5 & 29 & 38 & 20 & 26 \\
\hline The school head conducts meetings regularly & 8 & 11 & 14 & 18 & 1 & 1 & 34 & 45 & 19 & 25 \\
\hline $\begin{array}{l}\text { The head is available with an open door to staff } \\
\text { members }\end{array}$ & 6 & 8 & 10 & 13 & 4 & 5 & 38 & 50 & 18 & 24 \\
\hline The head actively listens with understanding ear & 10 & 13 & 17 & 22 & 1 & 1 & 30 & 40 & 18 & 24 \\
\hline $\begin{array}{l}\text { The school head shows respect to staff members } \\
\text { and values everyone's input }\end{array}$ & 8 & 11 & 10 & 13 & 1 & 1 & 32 & 42 & 25 & 33 \\
\hline $\begin{array}{l}\text { The head communicates knowledge, vision and } \\
\text { mission }\end{array}$ & 6 & 8 & 8 & 11 & 0 & 0 & 37 & 49 & 24 & 32 \\
\hline
\end{tabular}

\section{Source: Field data 2021}

Key: $f=$ Number of respondents and $\%=$ Percentages

Findings in table 1 show that $68 \%$ of teachers agreed that the school head tries to provide all information needed to accomplish the task while $22 \%$ indicated that their school head do not provide all the information needed to accomplish the task. This means that not all school heads provide all the information needed to accomplish the task which may be due to lack of skills on how to accomplish it. This means that majority of school heads in Tarime District tries to provide all the information needed to accomplish the task in communication matters as they were trained in during ADEM in-service training program. This confirms Human relation theory which provides communication as one of the feature which is the result of reciprocal understanding of all factors in the situation (Luenendonk, 2019). During the interview with non teaching staff the same question item was addressed to them. One of them had this to say: "our school head clearly provides all the information on what is supposed to be done though most of the time is found to be too much for me" (8, July, 2021)

The findings from table 1 presents that $67 \%$ of teachers agreed that school heads in Tarime District specifies clearly the results needed in their schools while 33\% indicated that they disagreed with the statement. This means that most of school heads in Tarime District specifies clearly the results needed in communicating with students and staff members in enhancing human relations as ADEM in-service training program trains them. The findings are supported by Janse (2019) who asserted that communication is taken to be very important and a reciprocal for the mutual understanding between the leader and the subordinates; this is to be used to solve different challenges which may arise between the two parties because of their differences.

From the findings in table 1 teachers' responses revealed that $74 \%$ of teachers who participated in the study agreed that their school head involves teachers in problem solving while $25 \%$ of teachers indicated that their school heads do not involve them in problem solving. The findings show that teachers are involved in problem solving in school operations. These findings are different from those collected from non teaching staff for one of them said: "we are not involved in solving problems most of the time we receive order on what to be done" (8, July, 2021). This means that school heads work well with teachers but neglect non teaching staff. This implies 
that they needed to receive some skills which can enable them to involve all staff members in problem solving for effective communication to enhance human relations of public secondary school heads. The findings concurs with that of Mathew (2017) who found that effective and defined communication skills of the heads of schools influence positively teachers' motivation in terms of conflict resolution and problem solving skills for schools.

Findings on table 1 indicate that $74 \%$ of teachers who participated in the study agreed that their school heads make follow up and maintain accountability as they communicate in their schools and $26 \%$ of teachers revealed that their school heads do not make follow up to maintain accountability. This means that school heads making follow up and maintaining accountability in communication matters as part of human relations was effective though they need to receive some skills on how they can make it effective for human relations. Effective accountability increase teachers performance and commitment as it was revealed by Kanani (2018) The findings show that the implementation of effective administrative communication portrays significant impact to teachers' performance and their commitment.

From table 1 it was indicated that $64 \%$ of teachers agreed that their school heads gives the required information on time as they communicate while $31 \%$ of teachers indicated that their school heads do not give the required information on time as they communicate in school matters. This showed that majority of school heads dives the required information on time and few of them were showed not to fulfill the task effectively. This indicates that there is a need to strengthen this aspect by in-service training program to equipping them with communication skills in managing human relations which in turn brings unity among school members. This is very important as it was suggested by Mohamed (2012) that communication was not effective in connecting teachers, non teaching staff, students and parents with secondary school heads.

From table $1,70 \%$ of teachers who participated in the study agreed that their school heads conduct meetings regularly with teachers and $29 \%$ of teachers indicated that their school heads do not conduct meetings regularly. On contrary, one of the non teaching staff said "most of the time we are not involved in meetings but only $i$ receive orders from the management on what was agreed in the meetings concerning my work" (8,July,2021). Another non teaching staff confirmed that: "we are not given chances to attend meetings on where we can express our views because we are not teaching”. This shows that majority of school heads conducts meetings regularly to communicate school matters with teachers neglecting other staff members who are not teaching. This shows that for them to be effective they need to be equipped with communication skills so that they can know how to integrate staff members to solve their challenges through meetings. This can be the great cause of problem in schools as Darma (2016) argues that communication problems span from implementation of a meeting, reminder of academic calendar program, to personal matters that occur among individuals within the school. Shaban (2017) cements this idea by emphasizing that heads of school should use instructional leadership strategies which give chance for the teachers to participate in the school activities by conducting frequent meetings to discuss and solve their problems.

From the findings in table 1 teachers' responses indicated that $74 \%$ agreed that their school head is available with an open door to staff members while $21 \%$ of teachers who participated in the study showed that their school heads were not available with an open door to staff members. This shows that majority of school heads were available to teachers with an open door to listening and understanding for human relations though this aspect need to be improved. The responses from teachers were positively supported by the responses from interviews. During the interview session one of the non teaching staff said "Our school head tries to be available with an open door to staff members but not to all staff because others are neglected and others are favored" $(6, J u l y, 2021)$. The findings replies the order of Regional Commissioner of Shinyanga Zainab Telack on Feb $4^{\text {th }}$ 2020 during her meeting with all school heads ordered by insisting on effective communication; having their doors open and being friendly to teachers, students and parents creating conducive teaching and learning climate.

Findings in table 1 showed that $64 \%$ of teachers agreed that their school head shows respect to staff members and values everyone's input however, 35\% of teachers indicated that their school heads do not show respect to staff members and value everyone's input. On the other hand one of the non teaching staff during interview said: "Not everyone is valued because those who have high education are valued much than us". Another added that: "Even we are not motivated to add up effort on our work since our efforts are not seen by our school head..." (6, Julay,2021). This shows that majority of school heads show respect to staff members and value their input and that there are some school heads who do not respect and value their staff. The ideal situation is that every individual should be respected and valued. The human relation theory recognises the subordinates as human beings with their needs, beliefs, perceptions and values that they should be given opportunities to enhance personal growth and development. Sabanci (2016) insists that the result of school heads' communication skills in empathic sensitivity, reflective listening and feedback and creating positive communication climate to bring satisfactory level in schools.

Furthermore From findings in table 1 teachers' responses showed by $81 \%$ that their school heads communicates knowledge, vision and mission and $19 \%$ of teachers showed that their school heads communicate knowledge, vision and mission of their schools. This means that majority of staff members know the school 
goals, vision and mission because their school heads communicates to them. However school heads need to be trained on how to communicate knowledge, vision and mission through ADEM in-service training program for effective attainment of institutional goals and that of the National at large as human capital theory insists. The Human Capital Theory suggests that increased quality of training of school heads is associated with higher individual performance of school head, higher creativity, lower indiscipline cases and great ability in problem solving at school.

The finding presented in the table 2 summarizes the responses of students on communication skills of school heads in managing human relation.

Table 2 Summary of Students' responses on Communication skills of Heads of Schools $N=192$

\begin{tabular}{|c|c|c|c|c|c|c|c|c|c|c|}
\hline & \multicolumn{2}{|c|}{$\begin{array}{c}\text { strong } \\
\text { disagree }\end{array}$} & \multicolumn{2}{|c|}{ disagree } & \multicolumn{2}{|c|}{ undecided } & \multicolumn{2}{|c|}{ agree } & \multicolumn{2}{|c|}{$\begin{array}{l}\text { strong } \\
\text { agree }\end{array}$} \\
\hline & $\mathrm{f}$ & $\%$ & $\mathrm{f}$ & $\%$ & $\mathrm{f}$ & $\%$ & $\mathrm{f}$ & $\%$ & $\mathrm{f}$ & $\%$ \\
\hline $\begin{array}{l}\text { The head provides the information needed for a } \\
\text { task }\end{array}$ & 14 & 7 & 33 & 17 & 8 & 4 & 88 & 46 & 49 & 26 \\
\hline The head specifies clearly the results needed & 13 & 7 & 20 & 10 & 6 & 3 & 92 & 48 & 61 & 32 \\
\hline The head involves students in problem solving & 17 & 9 & 20 & 10 & 7 & 4 & 86 & 45 & 62 & 32 \\
\hline $\begin{array}{l}\text { The head treats students with respect by valuing } \\
\text { everyone's input }\end{array}$ & 22 & 11 & 22 & 11 & 8 & 4 & 78 & 41 & 62 & 32 \\
\hline $\begin{array}{l}\text { The head conducts meetings with students } \\
\text { regularly }\end{array}$ & 18 & 9 & 24 & 12 & 9 & 5 & 81 & 42 & 60 & 31 \\
\hline $\begin{array}{l}\text { The head is available with open door to all } \\
\text { students }\end{array}$ & 20 & 10 & 34 & 18 & 0 & 0 & 78 & 41 & 60 & 31 \\
\hline $\begin{array}{l}\text { The head actively listens students with } \\
\text { understanding }\end{array}$ & 16 & 8 & 23 & 12 & 7 & 4 & 80 & 42 & 66 & 34 \\
\hline $\begin{array}{l}\text { The head communicates knowledge, vision and } \\
\text { mission }\end{array}$ & 17 & 9 & 25 & 13 & 0 & 0 & 88 & 46 & 62 & 32 \\
\hline $\begin{array}{l}\text { The head does not give the required information } \\
\text { on time }\end{array}$ & 55 & 29 & 92 & 48 & 8 & 4 & 21 & 12 & 16 & 8 \\
\hline $\begin{array}{l}\text { The school head does not respect students' } \\
\text { views }\end{array}$ & 44 & 23 & 90 & 46 & 0 & 0 & 25 & 13 & 54 & 28 \\
\hline
\end{tabular}

Source: Field data 2021

Key: $f=$ Number of respondents and $\%=$ Percentages.

Findings in table 2 on students' responses showed that $72 \%$ of students who participated in the study agreed that their school heads tries to provide all the information needed to students to accomplish the task while $24 \%$ of students revealed that their school heads do not provide all the required needed to students to accomplish the task. This means that majority of school heads in Tarime District tries to provide all the information needed to accomplish the task in communication matters as they were trained in during ADEM in-service training program. Provision of the needed information to accomplish the task is very important because the leader do not work alone there should be a free interchange of information. This is confirms Human relation theory that all leaders work through people and with people, hence they must be sensitive to the human factor and organization structures should allow for free interplay since leadership is about shared responsibilities.

The findings from table 2 presents that $80 \%$ of Students who participated in the study agreed that their school heads specifies clearly the results needed and $17 \%$ indicated that their school heads do not specify clearly the results needed when communicating with students to enhance human relations as ADEM in-service training program trains them. This means that majority of school heads on communicating with students specifies clearly the results needed in the school. The findings are in line with Ndidi et al (2013) who found that many school heads possessed the managerial skills for effective management of secondary school for national transformation after their training.

From the findings in table 2 Students' responses indicated that majority (77\%) agreed that their school heads involve students in problem solving while $19 \%$ of students indicated that their school heads do not involve them in problem solving in school operations. Involvement of students in problem solving brings a friendly environment which reduces indiscipline cases then enhancing human relations. The findings concurs with that of Masalu, (2018) who confirmed that students' indiscipline cases in secondary schools in Tanzania were caused mostly by lack of friendly school environment. Teachers' responses showed the same results that they were involved in problem solving. When the same question was directed to non teaching staff during interview they had a contrary opinion that majority of school heads were not involving staff members in problem solving. This implies that most of school heads work well with teachers and students in problem solving than non teaching staff. If this is the situation there is a need to give school heads some skills which can enable them to involve students and staff members in problem solving for effective communication to enhance human relations of 
public secondary school heads.

Findings in table 2 indicate that $77 \%$ of students who participated in the study indicated that their school heads gives the required information on time while only $19 \%$ of students showed that their heads do not give the required information on time in communication matters as a component of human relations. This indicates that majority of school heads use communication skills to give all the required information on time to students while few of them had no such skill. To make it effective the in-service training program could be the solution for them to use the skill effectively to strengthened the internal mechanisms. One of internal mechanism of improving performance is to communicate the required information on time as Mosha \& Chua (2015) revealed that internal mechanisms for improving performance of schools to be mainly attributed to the kind of management available in a particular school, which ensures availability of workable and agreed on mechanisms of providing effective teaching and learning.

From table 2,74\% of students who participated in the study agreed that their school heads conducts meetings regularly with students however, $21 \%$ of students who responded to this item disagreed that their school heads do not conducts meetings regularly as part of communication. The findings agrees with the response from teachers who also indicated that their school heads conducts meetings regularly with them although non teaching staff indicated that most of the time they were ignored not involved in meetings and most of the time only receives orders. This shows that majority of school heads conducts meetings regularly and few of them rarely conduct meetings to communicate school matters and enhance human relations. This implies that for them to be effective they need to be equipped with communication skills so that they can solve their challenges through meetings. This is very important so as to avoid some problems as it was revealed by Darma (2016) that the communication problems span from implementation of a meeting, reminder of academic calendar program, to personal matters that occur among individuals within the school.

From the findings in table 2 responses indicated that $72 \%$ of students agreed that their school heads are available with an open door to them while $28 \%$ of students who participated in the study they indicated that their school heads were not available with an open door to all students. Teachers' response indicated that their school heads were always available with the open door to them which was not the case to non teaching staff who revealed that there were others who were not received well by their school heads. This shows that majority of school heads are always available to teachers and students with an open door to listening and understanding for human relations but non teaching staff were ignored. The school head should be a link between all community members without any bias. This gap of performance need to filled through in-service training. The findings concurs with Sabanci (2016) who indicated the result of school heads' communication skills in empathic sensitivity, reflective listening and feedback and creating positive communication climate to bring satisfactory level in schools.

Findings in table 2 show that $73 \%$ of students who were involved in the study agreed that their school heads show respect to students and value everyone's input while $22 \%$ of students showed that their school heads did not show respect to students and value everyone's input. This shows that majority of school heads show respect to students and values their input and few school heads do not show respect to them and do not value their input. During interview the same question was directed to one of non teaching staff who also confirmed by saying: "Our school head tries to show respect to workers especially when I bring some suggestion to improve my work" (6, July, 2021). This implies that to some extent school heads uses communication skills to bring respect to all community as Nyamubi (2017) insisted that teachers' friendship and cooperation with coworkers and students as well as the respect of community members enhances their satisfaction in teaching and learning in the school.

From findings in table 2 students' responses showed by $78 \%$ that their school heads communicates knowledge, vision and mission to students while $22 \%$ of students who participated in the study indicated that their school heads do not communicates knowledge, vision and mission to them. This means that majority of staff members and students know the school vision and mission because their school heads communicates to them. However school heads need to be trained on how to communicate knowledge, vision and mission through ADEM in-service training program as human capital theory insists that This is very important because Human Capital Theory (HCT) suggests that increased quality of training of school heads are associated with higher individual performance of school head, higher creativity, lower indiscipline cases and great ability in problem solving at school. It was also supported by Kamete (2014) that school heads should employ communication skills to convey the right message to their academic staff, regarding poor performance of students and its impact in economic as well as social development of citizens.

The finding presented in the table 3 summarizes the responses of public secondary school heads who attended ADEM in-service training program on their communication skills in managing human relation. 
Table 3 Summary of Responses of School Heads who attended ADEM in-service training program on their communication skills $N=4$

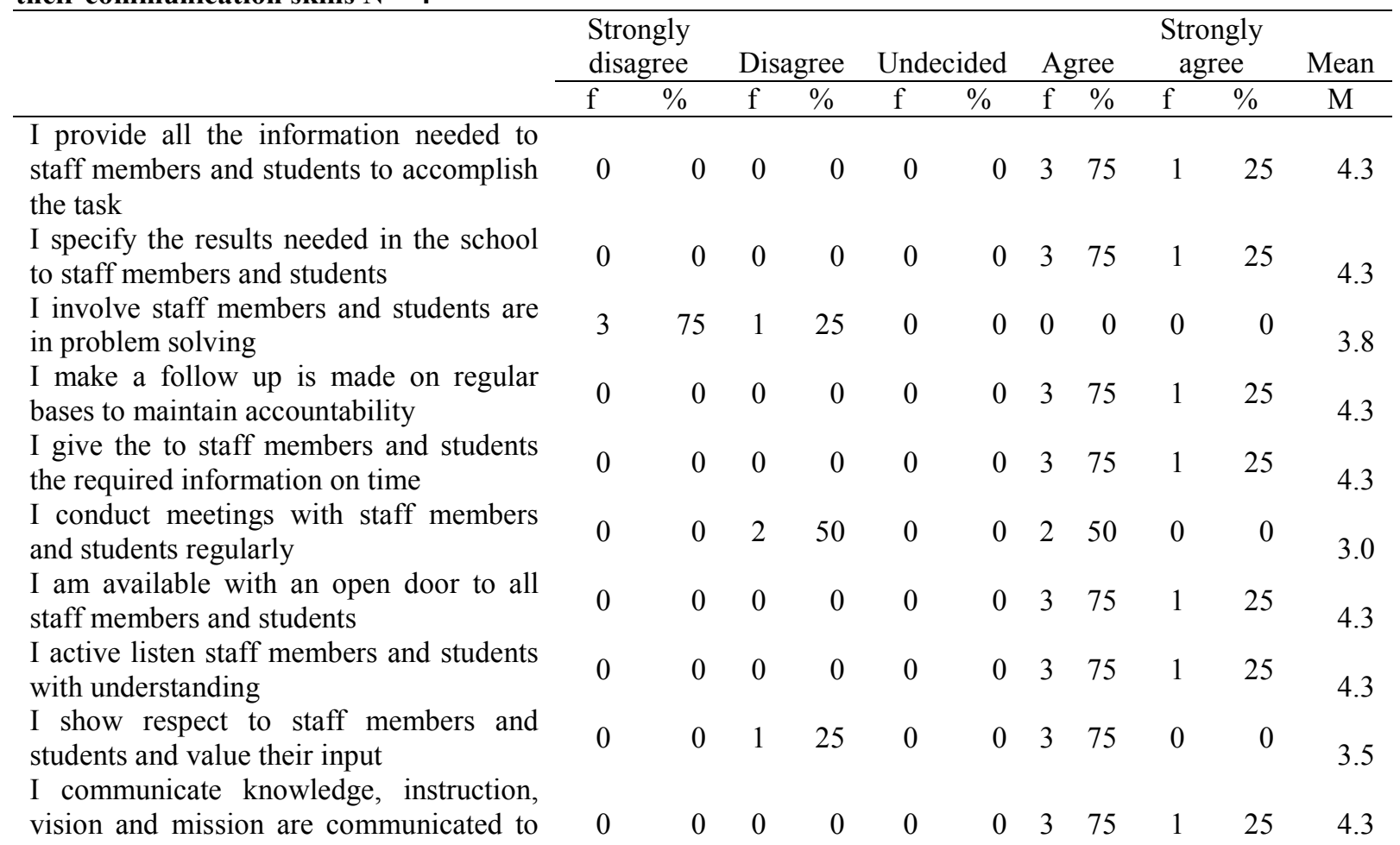

\section{Source: Field data 2021}

\section{Key: $\mathbf{f}=$ Number of respondents and $\%=$ Percentages.}

Findings in table 3 on school heads who attended ADEM in-service training program responded by $100 \%$ that they try to provide all the information needed to staff members and students to accomplish the task in their schools. This finding concurs with that of teachers and students' responses who also showed that they agree with that their school heads tries to provide all the information needed to them to accomplish the task. On contrary one of non teaching staff revealed that it needs to be improved. This means that all school heads in Tarime District who attended the program provides all the information needed to teachers and students to accomplish the task in communication matters as they were trained in during ADEM in-service training program. This means that they work well with teachers and students neglecting non teaching staff that they need to renew their communication skills on all the workers. This was confirmed by human relation theory which insists that all leaders work through people and with people, hence they must be sensitive to the human factor and organization structures should allow for free interplay since leadership is about shared responsibilities.It was confirmed by Kamete (2014) that head of schools should employ communication skills to convey the right message to their academic staff, regarding poor performance of students and its impact in economic as well as social development of citizens.

The findings from table 3 presents that $100 \%$ of school heads who attended ADEM in-service training program indicated that they specify clearly the results needed in their schools. The findings agree with those of teachers and students who showed that most of their school heads in Tarime District specifies clearly the results needed in communicating with students and staff members in enhancing human relations as ADEM in-service training program trains them. This kind of relationship is central to any leader as Janse (2019) asserts that communication is taken to be very important and a reciprocal for the mutual understanding between the leader and the subordinates; this is to be used to solve different challenges which may arise between the two parties because of their differences. This is very important as it is presented by Githiari, (2017) that school heads are expected to be highly skilled leaders in order to be effective in attaining school goals.

From the findings in table 3 school heads who attended ADEM in-service training program indicated by $100 \%$ that they do not involve staff members and students in problem solving. The findings agree with those of teachers and students that they are not involved in problem solving in school operations. The findings concurs with what TETP (2014) aims at ensuring personnel with skills for sustaining peace, to endure and resolve conflicts and ethics by fostering unity and solidarity. This is to realize that they needed to receive some skills 
which can enable them to involve students and staff members in problem solving for effective communication to enhance human relations of public secondary school heads. Effective communication creates a very amicable working environment as Mathew (2017) maintains that effective and defined communication skills of the heads of schools influence positively teachers' motivation in terms of conflict resolution and problem solving skills for schools. Obembe (2014) supports the views by insisting that, the involvement of teachers in decision making has positive effects on students' discipline.

From table 3 the results indicate that $100 \%$ of school heads who attended ADEM in-service training program indicated that they give the required information on time in communication matters as a component of human relations. The findings reveal some weaknesses in the communication systems in schools. This showed that school heads were not effective in giving the required information to students on time. This calls for strengthening of the in-service training program in order to effectively equip school heads with communication skills to enhance human relations in public secondary school heads which in turn brings unity among school members. This is confirmed by human relation theory which insists that that all leaders work through people and with people, hence they must be sensitive to the human factor and organization structures should allow for free interplay since leadership is about shared responsibilities.

From table 3, 50\% of school heads who attended ADEM in-service training program showed that they conduct meetings regularly with students and staff members however, $50 \%$ of school heads who responded to this item indicated that they do not conduct meetings with staff members and students regularly as part of communication. The finding agrees with the response from teachers, students and non teaching staff who also indicated the same. This shows that some of school heads who attended the program conduct meetings regularly with school members and some do not use communication skill to unite school members in meetings. This is an indication that ADEM trainings need to be strengthened. It is expected that regular meetings are avenue for HoS to give directives to subordinates. Shaban (2017) insists that heads of school should use instructional leadership strategies which give chance for the teachers and students to participate in the school activities by conducting frequent meetings to discuss and solve their problems.

From the findings in table 3 all school heads who attended ADEM in-service training program said that they were available with an open door to staff members and students. Teachers and students' response confirms the findings. This implies that the school community members can air out their views on various issues and sort out differences thus creating a conducive working environment. However, the situation in schools is not all roses as non teaching staff complained during interviews to have been ignored. This gap of performance need to filled through in-service training to aid the good communication network to avoid conflicts. Isalu (2017) suggests that there should be regular staff meetings, good communication network and the teachers' and students' code of conduct should be made available to all staff and students so as to know their limit and avoid conflict.

Findings in table 3 showed that $75 \%$ of school heads who attended ADEM in-service training program revealed that they show respect to staff members and students and value everyone's input. The finding concurs with those obtained from majority of teachers and students. This is according to the country education policy which aims at ensuring personnel with skills for sustaining peace, to endure and resolve conflicts and ethics by fostering unity and solidarity.

From findings in table 3 school heads who attended ADEM in-service training program showed by $100 \%$ that they school heads communicates knowledge, vision and mission to staff members and students. This implies that most of school heads who attended the program uses communication skills to make realization of educational goals contrary to Massawe, (2014) who indicated that schools heads failed to articulate and involve teachers and students in realizing the school goals and mission due to lack of managerial skills

The finding presented in the table 4 summarizes the responses of public secondary school heads who never attended ADEM in-service training program on their communication skills in managing human relation. 
Table 4 Summary of Responses of School Heads who did NOT attend ADEM in-service training program on their communication skills $N=4$

\begin{tabular}{|c|c|c|c|c|c|c|c|c|c|c|c|}
\hline & \multicolumn{2}{|c|}{$\begin{array}{l}\text { Strongly } \\
\text { disagree }\end{array}$} & \multicolumn{2}{|c|}{ Disagree } & \multicolumn{2}{|c|}{ Undecided } & \multicolumn{2}{|c|}{ Agree } & \multicolumn{2}{|c|}{$\begin{array}{l}\text { Strongly } \\
\text { agree }\end{array}$} & \multirow{2}{*}{$\frac{\text { Mean }}{\mathrm{M}}$} \\
\hline & $\mathrm{f}$ & $\%$ & $\mathrm{f}$ & $\%$ & $\mathrm{f}$ & $\%$ & $\mathrm{f}$ & $\%$ & $\mathrm{f}$ & $\%$ & \\
\hline $\begin{array}{l}\text { I provide all the information needed to } \\
\text { staff members and students accomplish } \\
\text { the task }\end{array}$ & 0 & 0 & 0 & 0 & 0 & 0 & 3 & 75 & 1 & 25 & 4.3 \\
\hline I specify the results needed in the school & 0 & 0 & 1 & 25 & 0 & 0 & 3 & 75 & 0 & 0 & 3.5 \\
\hline $\begin{array}{l}\text { I do not involve staff members and } \\
\text { students in problem solving }\end{array}$ & 0 & 0 & 2 & 50 & 0 & 0 & 2 & 50 & 0 & 0 & 3.0 \\
\hline $\begin{array}{l}\text { I make a follow up on regular bases to } \\
\text { maintain accountability }\end{array}$ & 0 & 0 & 2 & 50 & 0 & 0 & 2 & 50 & 0 & 0 & 3.0 \\
\hline $\begin{array}{l}\text { I give the required information to staff } \\
\text { members and students on time }\end{array}$ & 0 & 0 & 1 & 25 & 0 & 0 & 3 & 75 & 0 & 0 & 3.5 \\
\hline $\begin{array}{l}\text { I conduct meetings regularly with staff } \\
\text { members and students }\end{array}$ & 0 & 0 & 1 & 25 & 0 & 0 & 2 & 50 & 1 & 25 & 3.8 \\
\hline $\begin{array}{l}\text { I am available with an open door to all } \\
\text { staff members and students }\end{array}$ & 0 & 0 & 2 & 50 & 0 & 0 & 2 & 50 & 0 & 0 & 3.0 \\
\hline $\begin{array}{l}\text { I listen staff members and students } \\
\text { actively with understanding }\end{array}$ & 0 & 0 & 0 & 0 & 0 & 0 & 3 & 75 & 1 & 25 & 4.2 \\
\hline $\begin{array}{l}\text { I show respect staff members and } \\
\text { students are shown respect by valuing } \\
\text { their input }\end{array}$ & 0 & 0 & 0 & 0 & 0 & 0 & 3 & 75 & 1 & 25 & 4.2 \\
\hline $\begin{array}{l}\text { I communicate knowledge, instruction, } \\
\text { vision and mission of the school }\end{array}$ & 0 & 0 & 0 & 0 & 0 & 0 & 3 & 75 & 1 & 25 & $\begin{array}{r}4.2 \\
3.67 \\
\end{array}$ \\
\hline
\end{tabular}

Source: Field data 2021

Key: $\mathbf{f}=$ Number of respondents and $\%=$ Percentages

Findings in table 4 show responses of school heads who never attended ADEM in-service training program. Majority of them (75\%) agreed that they provide all the information needed to staff members and students to accomplish the task in their schools. On the other hand others indicated by $25 \%$ strongly agreed that they provide all the required information needed to staff members and students to accomplish the task. This finding concurs with that of teachers and students' responses who also agreed that their school heads tries to some extent to provide all the information needed to them to accomplish the task. However, findings from non teaching staff revealed that it needed to be improve this aspect of communication in the management of human relations. This means that because of this contradicting information all school heads in Tarime District who never attended the program lack some skills for them to provide all the information needed to teachers and students to accomplish the task in communication matters for human relations. It calls for the need of in-service training as per the aim of the country through the policy TETP (2014) of ensuring personnel with skills for sustaining peace, to endure and resolve conflicts and ethics by fostering unity and solidarity.

The findings from table 4 presents that $75 \%$ of school heads who never attended ADEM in-service training program indicated that they specify clearly the results needed in their schools. On the other hand other $25 \%$ of school heads who never attended the program indicated that they do not specify the results needed to staff members and students. This means that majority of school heads who did not attend the program use communication skill to specify clearly the results needed in the school. The findings agrees with that of teachers and students who showed that most of their school heads in Tarime District specifies clearly the results needed in communicating with staff members and students in enhancing human relations. This means that school heads need to be equipped with communication skills so as to be effective in managing human relations. This is important to overcome the challenges showed by Ndidi et al (2013) found that many school heads do not possess the managerial skills for effective management of secondary school for national transformation.

From the findings in table 4 school heads who never attended ADEM in-service training program indicated by $50 \%$ that they always involve staff members and students in problem solving while $50 \%$ showed that they do not involve staff members and students in problem solving. The findings from teachers and students show that staff members and students are involved in problem solving in school operations to some extent. This is to realize that school heads need to be equipped with some skills which can enable them to involve students and staff members in problem solving for effective communication to enhance human relations of public secondary school heads. Since this is the aim of the country according to the TETP (2014) that education for peace should 
focus on helping students to have the capacity to stop and resolve conflicts peacefully when such conflicts occur among the people, between the people or among groups involved in schools.

From table 4 the results indicate that $75 \%$ of school heads who never attended ADEM in-service training program indicated that they give the required information on time while $25 \%$ of school heads who never attended the program showed that they agreed strongly that they give the required information on time in communication matters as a component of human relations. This showed that school heads were not effective in giving the required information to students on time that they needed to be strengthened by in-service training program for equipping the communication skills to enhance human relations skill of public secondary school heads which in turn brings unity among school members. This is to emphasize involvement of school members so as to avoid deviant behaviour as Gossen (2016) argued that a school head that plays the role of an absolute dictator may directly or indirectly causes deviant behaviors. Therefore they need to be equipped with skills through in-service training program to ensure conducive working condition to all members of the school.

From table 4, 50\% of school heads who never attended ADEM in-service training program showed that they always conduct meetings regularly with students and staff members however, $50 \%$ of school heads who responded to this item indicated that they do not conduct meetings with staff members and students as part of communication. The finding agrees with the response from teachers, non teaching staff and students who also revealed the same. This is to show that for them to be effective they need to be equipped with communication skills so that they can solve their challenges through meetings. To ensure the implementation, the education sector needs knowledgeable personnel who are able to supervise and manage the provision of education to the public by creating a conducive peaceful environment for learning and future responsible citizen (TETP, 2014) as per the aim of ADEM.

From the findings in table 4 school heads who never attended ADEM in-service training program indicated by $50 \%$ that they are available with an open door to staff members and students while others indicated by $50 \%$ that they showed that they were not available with an open door to staff members and students. Teachers and students' response indicated that their school heads were available with the open door to them to some extent. This was not the case to non teaching staff who revealed that there are others who are not received well by their school heads. This shows that majority of school heads are always available to teachers and students with an open door to listening and understanding for human relations but non teaching staff are ignored. This gap of performance need to filled through in-service training. Matenga (2014) revealed that conflicts at their institutions were caused by bad leadership style and poor communication especially failure to listen to people views.

Findings in table 4 showed that $75 \%$ of school heads who never attended ADEM in-service training program revealed that they shows respect to staff members and students and values everyone's input. This shows that majority of school heads show respect to students and values their input though teachers and students' responses shows that few school heads do not show respect to them and do not value their input. This was also confirmed by one of non teaching staff who indicated that not everyone is valued that there is some element of discrimination against their level of education. This needs to be cleared by making it effective because everyone has their values needs and their input in the school; this gap has to be bridged by ADEM in-service training program to enhance human relations. Isalu (2017) suggests that there should be regular staff meetings, good communication network and the teachers' and students' code of conduct should be made available to all staff and students so as to know their limit and avoid conflict. The skill and knowledge to be obtained through in-service training of school heads.

From findings in table 4, all school heads who never attended ADEM in-service training program showed that they communicates knowledge, vision and mission to staff members and students. This means that majority of staff members and students know the school vision and mission because their school heads communicates to them. However school heads need to be trained on how to communicate knowledge, vision and mission through ADEM in-service training program as Human capital theory emphasizes that education increases the productivity and efficiency of workers by increasing the level of cognitive stock of productive human capability; as a product of innate abilities and investment in human beings.

\section{Conclusions and Recommendations}

The study concluded that majority of school heads in Tarime District who attended ADEM in-service training program provide use communication skill in managing human relations as they were trained in during the program but only they need to improve the use of the skill. On the other hand majority of school heads who never attended the program lack some skills in the management of human relations especially in communication skill.

The study recommends that for public school heads should be equipped with communication skills so that they can solve different challenges facing their schools. The program is recommended for all school heads especially those who haven't attended the program for they lack some skills on communication for human relation. 


\section{References}

Akinola, O. (2013). Principals' Leadership Skills and School Effectiveness: The Case of South Western Nigeria.

Auma, C. (2014). The Effects of Leadership Styles in Promoting Academic Performance in Rorya District, Tanzania.

Chumutai, E. (2014). Challenges facing Principals on their roles as Human Resource Managersin Secondary schools in Nandi County Kenya.

Darma, I. (2016). Communication Problems among Principles, Vice Principles, and Teachers in an Indonesian Secondary Schools. Indonesia.

Dawn, E. (2016). Communication behaviors of principals at high performing Title I Elementary schools in Virginia.

Gemech, D. (2014). The Practices of teachers' Involvement in Decision-making in Government Secondary schools of Jimma town, Ethiopia.

Githiari, F. (2017). Ways Through Which Principals Acquire the Leadership Competencies Required for Effective Management of Secondary Schools in Nairobi County, Kenya.

Hosea, M. (2015). Role of Head Teachers in Human Resource Management in Public Primary Schools in Suba Sub County.

Janse, B. (2019). Mary Parker Follett $\quad$ Contribution to Management .https://www.toolshero.com/management/mary-parker-follett-contribution-to-management/

Kaluma, E. (2017) Conflict Management in Secondary Schools in Tanzania: A Case of Selected Secondary Schools in Shinyanga Municipal Council, Tanzania.

Kambe, Y. (2011). The Impacts of Reforms on the Quality of Education in Tanzania: University of Dar es Salaam, Tanzania.

Kamete, J. (2014). The influence of headmaster's managerial skills on effective school management: a case of public secondary schools in Mbeya, Tanzania.

Kanani, M. (2018). Effectiveness of administrative communication system on teachers' performance in secondary schools in Singida Municipality, Tanzania.

Kayiwa, B. (2011) assessment of leadership training of head teachers and secondary school performance in Mubende District, Uganda.

Kerlinger, F. (2011).Research methods in Education. London: Rouledger Farmer.

Kevin, E. (2015). Leadership and Decision-Making Skills of High Poverty Elementary School Principals in an Era of Reduced Resources.

Kuluchumila, R. (2014). Preparation and development of secondary school heads: what should be done in Tanzania. Published by European Centre for Research Training and Development UK (www.eajournals.org)

Leithwood, K. (2005). Expert problem solving: Evidence from school and district leaders. Albany: State University of New York Press.

Luenendonk, M. (2019).Management theory of Mary Parker Follet. https://www.cleverism.com/managementtheory-of-mary-parker-follett/

Mabela, J. (2016). Roles of school management in handling career-related stress among teachers in secondary schools: a case of selected secondary schools in Tarime District, Tanzania. http://hdl.handle.net/20.500.12661/1240

Mahmoud, H. (2012). The Degree of Shared Decision Making Practice Towards The Principalsof Schools in Irbid City Schools From The Teachers Perspectives.

Masalu, J. (2018). An investigation into students' indiscipline cases in secondary schools in Tanzania.http://41.86.178.5:8080/xmlui/handle/123456789/4365

Masao, H. (2017). An assessment of secondary schools' head teachers Effective supervision in teaching and learning process in Kinondoni municipality.

Materu, S. (2016). Effectiveness of leadership and Management training Program for heads of secondary schools in Moshi District Council. Tanzania

Mathew, J. (2017). Influence of the heads of schools' human relation skills on job performance of teachers in public secondary schools in Moshi Municipality Tanzania.

Mgullah, S. M (n.d).A word from the chief executive. Retrieved on 22 October 2020, from http://adem.ac.tz/content/word-chief-executive

Mirunde, A. (2015). Training and professional development needs for Effective secondary school management in Nachingwea District. Tanzania.

Ndidi et al. (2013). Managerial Skills And Enhancement Strategies Of Secondary School Principals

Obembe, C. (2014). Human Resource Management in Education: Issues and challenges Abakaliki in Nigeria.

Ogutu, C. (2018). Teacher's body fires 27 teachers over absenteeism. https://www.thecitizen.co.tz/tanzania/news/teacher-s-body-fires-27-teachers-over-absenteeism-2639954 
Onguko, M et al. (2008). Exploring the Impact of School leadership on Pupil Outcomes. International Journal of Educational Management

Telack, Z. (2020). The meeting of school heads with Regional Commissioner (RC) of Shinyanga. http://www.shinyanga.go.tz/new/wakuu-wa-shule-watakiwa-kusimamia-taaluma- badala-ya-kushindakwenye-ofisi-za-halmashauri

http://www.tarimedc.go.tz/secondary-education

URT, (2014). Education Training Policy: Dar es Salaam: Ministry of Education and Culture.

Vishwanath, C. (2012). The Effects of Leadership Styles in Promoting Academic Performance in Primary Education. M.A. Ed Dissertation, University of Dar es Salaam, Tanzania.

Young, G. (2017). Analysis of human relations theory of management in school setting. 